\title{
Modern single-grain thermobarometry techniques applied to mantle xenocrysts from the Safartoq area, Greenland
}

\author{
Herman Grütter ${ }^{1}$, James Tuer ${ }^{2}$ \\ ${ }^{1}$ BHP Billiton World Exploration Inc., \#800 Four Bentall, 1055 Dunsmuir Street, Vancouver, B.C., V7X 1L2, \\ Canada. ${ }^{2}$ Hudson Resources, \#3050, 700 West Georgia Street, Vancouver, B.C., V7Y 1A1, Canada
}

\begin{abstract}
Introduction
The search for kimberlite-hosted diamonds in Greenland expanded rapidly in the mid-1990's, due largely to the activities of Canadian-funded exploration companies seeking opportunities beyond the confines of the Slave craton. According to some estimates, a total of some \$40-million was spent in the years 1994 to 2002 on diamond exploration in an area covering $60,000 \mathrm{~km}^{2}$. The kimberlitic indicator mineral (KIM) data generated by this effort has been captured by the Geological Survey of Denmark and Greenland (GEUS) with the help of reports supplied by the Bureau of Minerals and Petroleum (BMP) of Greenland, and made available digitally to interested parties at a cost of about $\$ 300$ (see Jensen et al., 2004). In this work we focus on applying modern single-grain thermobarometry techniques to the available microprobe data for $\sim 13,400$ clinopyroxene (cpx) and $\sim 6,750$ garnet (gar) grains that represent $\sim 1,600$ samples collected within a $1,000 \mathrm{~km}^{2}$ area located mostly to the south of Sondre Strom Fjord near Kangerlussuaq. Hudson Resources currently holds mineral exploration licenses over the area of interest.
\end{abstract}

\section{Single-cpx thermobarometry}

Compositional screening shows that some $95 \%$ of the 13,400 analysed cpx grains are derived from non-KIM sources (i.e. crustal sources), but single-cpx thermobarometry techniques (Nimis and Taylor, 2000) were applied to 436 mantle-derived cpx grains. Some $45 \%$ of these failed established compositional and mineralformula criteria that delimit valid P-T data (e.g. Nimis, 1998); the single-cpx P-T values calculated for the remaining 243 grains are shown in Figure 1. The P-T values constrain a cold geotherm at the time of kimberlite emplacement, circa 530 to $600 \mathrm{Ma}$ ago. The geotherm is well defined over the whole mantle temperature range and enters the diamond stability field at $\mathrm{T}>900^{\circ} \mathrm{C}$, as for the Slave craton (see Fig. 1). Kimberlites at Safartoq and in the Slave craton entrained mantle material to depths of $60 \mathrm{kbar}$, but mantle sampling at Safartoq occurred at $\mathrm{P}<36 \mathrm{kbar}$ and $\mathrm{T}<750^{\circ} \mathrm{C}$, shallower within the graphite stability field than for kimberlites of the Slave craton (Fig. 1). Differential entrainment of mantle with respect to graphite-diamond may therefore cause significant variability in diamond potential at Safartoq. We utilize Cr-pyrope thermobarometry to address this issue.

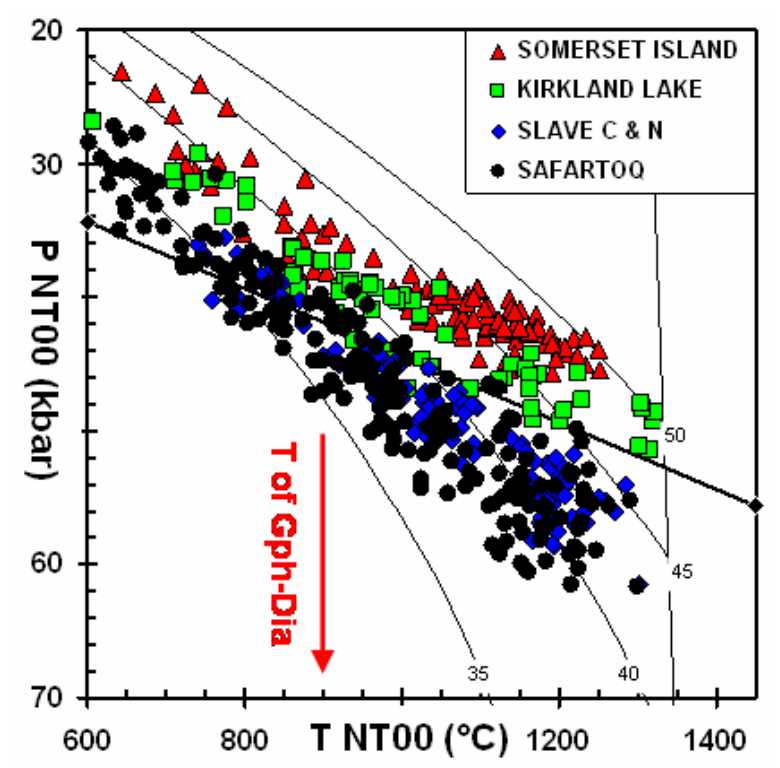

Fig. 1 Single-cpx P-T results for Safartoq. Data from Jensen et al. (2004).

\section{Cr-pyrope thermobarometry}

The Safartoq data set of Jensen et al (2004) contains 6,753 garnet analyses derived from $\sim 1,600$ samples, of which 624 analyses $(9 \%)$ represent non-KIM varieties. A conventional $\mathrm{Cr}_{2} \mathrm{O}_{3}$ vs $\mathrm{CaO}$ diagram for the $\mathrm{KIM}$ garnets is shown in Figure 2. G9 garnets are dominant and some high- $\mathrm{Cr}_{2} \mathrm{O}_{3}$ G10 garnets confirm the observation made from cpx barometry that the mantle section extends to $60 \mathrm{kbar}$ depth (based on the P38 $\mathrm{Cr} / \mathrm{Ca}$-garnet barometer of Grütter et al., 2006). LowCr G10 garnets are very well represented and their compositions extend to rare low $\mathrm{CaO}$ values, normally associated with extremely depleted, dunite-harzburgite protoliths with excellent inferred diamond potential. However, a low proportion of the Safartoq G10 garnets cross the graphite-diamond constraint (GDC) to higher $\mathrm{Cr}_{2} \mathrm{O}_{3}$ content, and this is cause for concern from an exploration perspective:- given the presence of significant graphite-facies cpx, the high-potential G10 garnets may be derived from shallower than the GDC, i.e. from inside the graphite stability field. The GDC is shown in Fig. 2 by a solid red line at $\mathrm{Cr}_{2} \mathrm{O}_{3}=0.94 \mathrm{CaO}$ +5 (after Grütter et al., 2006). 


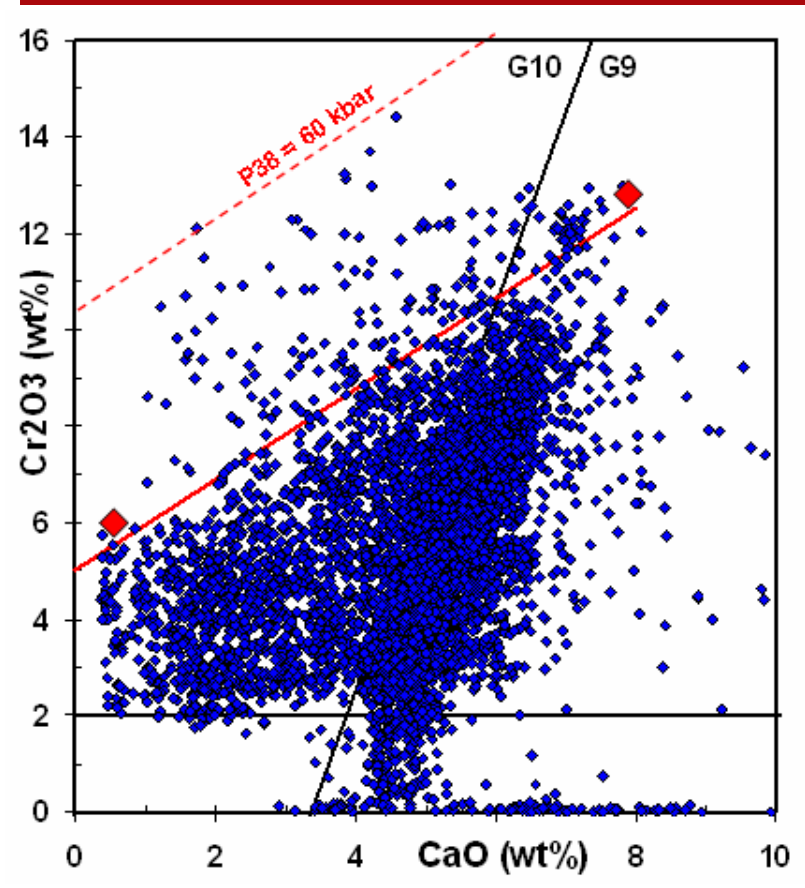

Fig. $2 \mathrm{Cr}_{2} \mathrm{O}_{3}-\mathrm{CaO}$ compositions of KIM garnets from Safartoq till samples. Data from Jensen et al. (2004).

A thermometric technique has to be used to locate $\mathrm{Cr}$ pyrope grains relative to graphite-diamond in a mantle section. We have applied an updated version of the Mn-in-garnet thermometer (T-Mn, Grütter et al, 1999) in combination with the garnet CA INT projection (Grütter et al., 2004) to construct a simplified garnetbased mantle section for Safartoq (Figure 3). G9 garnets (at CA_INT 3.4 to 5.4) occur throughout the whole mantle section, from $600^{\circ} \mathrm{C}$ to slightly over $1300^{\circ} \mathrm{C}$, the same temperature range as observed using cpx thermometry (cf. Fig. 1). Roughly half of all hightemperature garnets $\left(\mathrm{T}>1200^{\circ} \mathrm{C}\right)$ have $\mathrm{TiO}_{2}>0.6 \mathrm{wt} \%$ (not illustrated), consistent with $\mathrm{Fe}-\mathrm{Ti}$ metasomatism deep within the diamond stability field (DSF).

G10 garnets (with CA_INT < 3.4) from Safartoq also occur throughout the whole mantle section. Their average $\mathrm{CaO}$ content increases with depth, specifically within the $\mathrm{DSF}$ at $\mathrm{T}>900^{\circ} \mathrm{C}$. Although a relatively high proportion of all the KIM garnets from Safartoq are G10 varieties $(32 \%)$, Fig. 3 illustrates that the majority $(60 \%)$ are derived from within the graphite stability field, at $\mathrm{T}<900^{\circ} \mathrm{C}$. A further $28 \%$ of $\mathrm{G} 10$ 's are shallow diamond-facies grains $\left(900\right.$ to $\left.1100^{\circ} \mathrm{C}\right)$ and $12 \%$ are derived from deep within the diamond stability field (deep DSF, 1100 to $1300^{\circ} \mathrm{C}$ ). The Mnthermometry highlights that $20 \%$ of all KIM garnets in surficial samples from the Safartoq area are "deep DSF" grains, and only 1 in 5 of these is a G10 (Fig. 3). Differential sampling of the Safartoq mantle by a kimberlite magma would result in some unusual associations between G10 garnet and diamond: shallow mantle sampling would produce barren kimberlites carrying significant quantities of low-Cr G10 garnets, while diamondiferous kimberlites with deep mantle tenure would carry few G10 garnets, though with $\mathrm{Cr}_{2} \mathrm{O}_{3}$ content higher than the GDC (Fig. 2).

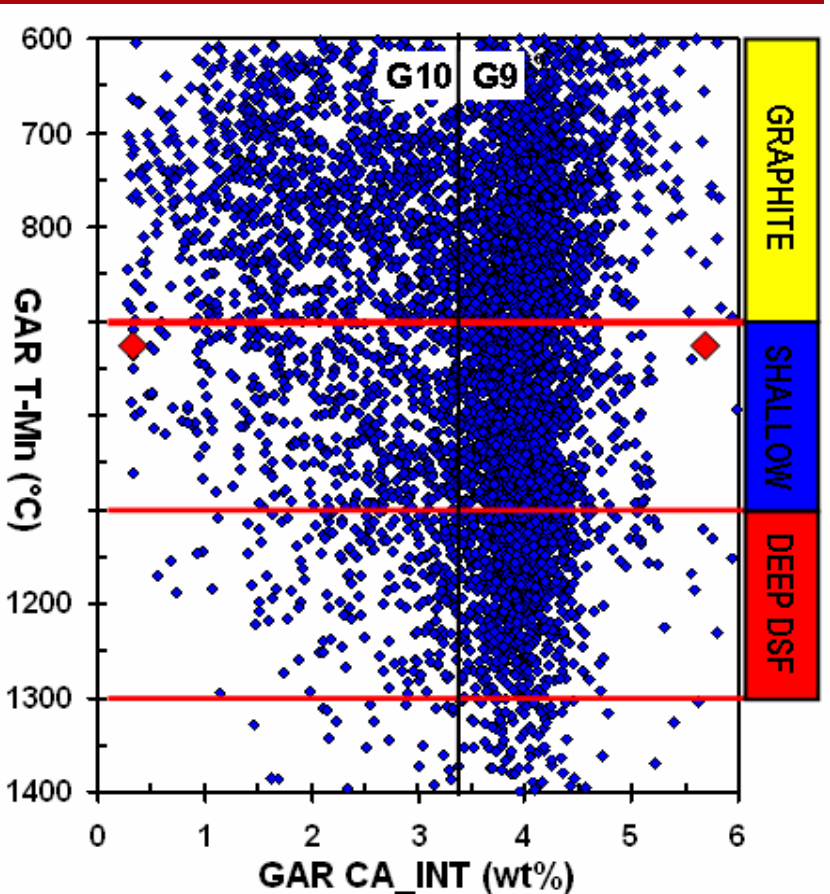

Fig. 3 Distribution of Safartoq Cr-pyrope compositions with temperature $(=$ depth). Mantle tenure classes are designated by yellow, blue and red color-coding.

\section{Mapping deep mantle tenure}

Categorization of KIM garnets by T-Mn class permits representation of mantle tenure at the scale of individual surficial sample results (Fig. 4). The garnet $\mathrm{T}-\mathrm{Mn}$ populations in most samples show graphitefacies $>$ shallow DSF $>>$ deep DSF tenure (yellow $>$ blue $>>$ red in Fig. 4). Kimberlite float collected from these areas has consistently produced barren or lowinterest microdiamond results ${ }^{1}$ and show similar mantle tenure - deep DSF grains are typically absent. Several discrete sources with dominantly deep mantle tenure (red $\geq$ blue $>>$ yellow) are evident in Fig. 4, and microdiamond results for kimberlite float collected from these select few localities typically endorse pursuit of the source ${ }^{2}$. Follow-up work at Garnet Lake isolated a high-interest $2.5 \mathrm{~m}$ thick kimberlite sheet with $3.0 \mathrm{~km}$ strike extent that currently is subject to advanced-stage bulk sampling and on-site recovery of commercial diamonds (see www.hudsonresources.ca for details). Additional follow-up exploration is in progress at Itisooq and other localities highlighted by deep mantle tenure (Fig. 4).

The mapping results for stream sediment samples collected within glacial valleys show well-mixed, homogenized mantle tenure (as expected, Fig. 4). These results poorly reflect the diamond-associated deep mantle tenure that occurs in-situ within basal till and related felsenmeer at the higher elevation of Garnet Lake, located only $8 \mathrm{~km}$ away. This observation emphasizes the point that garnet compositions such as shown in Figures 2 and 3 should not be construed as representing a true mantle section:- the incidence of KIM garnet compositions in an exploration-level data

\footnotetext{
see http://www.hudsonresources.ca/files/srcreport.pdf see map http://www.hudsonresources.ca/files/2005 Locations.pdf
} 


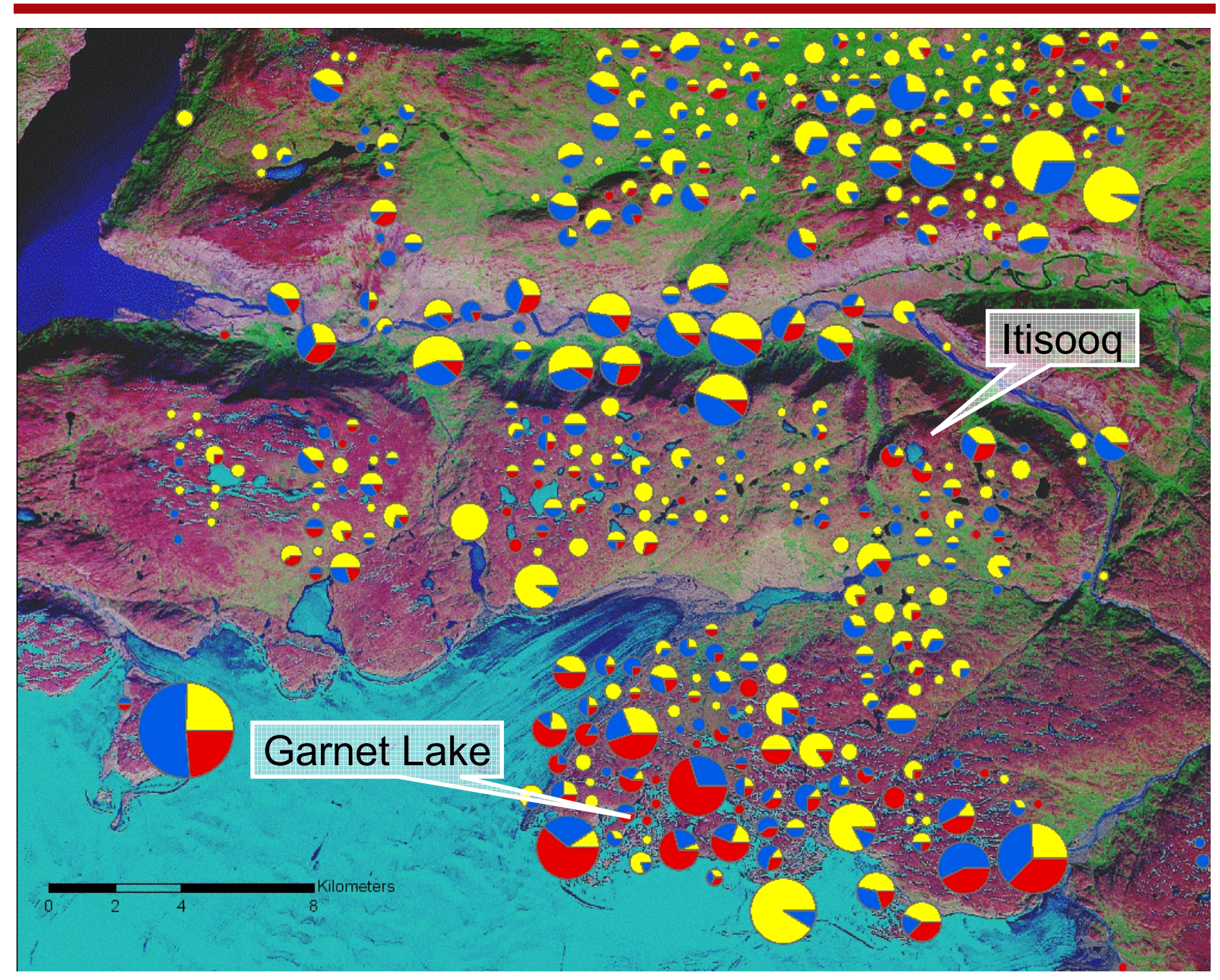

Fig 4. Mantle tenure classes (pie-chart colors) and KIM garnet abundance (pie chart sizes) in surficial samples from the Safartoq area. KIM compositions and sample locations are from Jensen et al (2004).

set depends on the extent of mixing in the secondary environment, the colour representation and quantity of concentrate garnets analysed, the distribution of harzburgitic or lherzolitic bulk compositions at depth within the lithosphere, and the vagaries of how such mantle rock types are entrained by, and disaggregate within, kimberlite magmas.

\section{Conclusions}

Application of modern single-grain thermobarometry and related techniques to public-domain, explorationlevel KIM cpx and gar compositions from Safartoq reveals (at $530-600 \mathrm{Ma}$ ):

- a cold cratonic geotherm.

- a depleted lithosphere extending to 60 kbar depth.

- deep mantle Fe-Ti metasomatism.

- an abundance of graphite-facies G10 garnets.

- differential depth entrainment of mantle by kimberlite magmas, expressed here as "mantle tenure".

- a clear correspondence of encouraging microdiamond results and potentially commercial macrodiamond results with deep mantle tenure.

\section{References}

Grütter, H.S., Apter, D.B., Kong, J., 1999. Crust-mantle coupling: evidence from mantle-derived xenocrystic garnets. In: Gurney, J.J., Gurney, J.L., Pascoe, M.D., and Richardson, S.H. (Eds.) Proceedings of the VIIth International Kimberlite Conference, Vol. 1, Red Roof Design, Cape Town, pp. 307-313.

Grütter, H.S., Gurney, J.J., Menzies, A.H., Winter, F., 2004. An updated classification scheme for mantle-derived garnet, for use by diamond explorers. Lithos 77, 841857.

Grütter, H., Latti, D. and Menzies, A., 2006. Cr-saturation arrays in concentrate garnet compositions from kimberlite and their use in mantle barometry. Journal of Petrology, 47, 801-820.

Jensen, S.M., Secher, K., Rasmussen, T.M., Schjoth, F., 2004. Diamond exploration data from West Greenland: 2004 update and revision. Geological Survey of Denmark and Greenland Report 2004/17, 90 pages with DVD disc.

Nimis, P. 1998. Evaluation of diamond potential from the composition of peridotitic chromian diopside. European Journal of Mineralogy, 10, 505-519.

Nimis P. and Taylor W. R., 2000. Single clinopyroxene thermobarometry for garnet peridotites. Part 1 . Calibration and testing of a Cr-in-Cpx barometer and an enstatite-in-Cpx thermometer. Contributions to Mineralogy and Petrology 139, 541-554. 